\title{
STATE ISLAMIC ORTHODOXIES AND ISLAMIC EDUCATION IN MALAYSIAAND INDONESIA
}

\section{Azmil Tayeb}

School of Social Sciences, Universiti Sains Malaysia, Pulau Pinang, MALAYSIA Email: azmil.tayeb@gmail.com

Published online: 25 September 2017

To cite this article: Azmil Tayeb. 2017. State Islamic orthodoxies and Islamic education in Malaysia and Indonesia. Kajian Malaysia 35(2): 1-20. https://doi.org/10.21315/km2017.35.2.1

To link to this article: https://doi.org/10.21315/km2017.35.2.1

\begin{abstract}
This paper compares state Islamic orthodoxy in Indonesia and Malaysia by using Islamic education curriculum for senior high schools as my case study. I argue that Malaysian Islamic Development Agency (Jabatan Kemajuan Islam Malaysia, JAKIM) in Malaysia has been more successful in exerting its orthodox values in the Islamic education curriculum than its counterpart Indonesian Council of Ulama (Majelis Ulama Indonesia, MUI) due to three factors: clear institutional objective; ideological cohesion among state institutions overseeing Islamic education; and patterns of Islamisation in the society that provide a conducive milieu for such orthodox ideals to thrive. In this paper I limit the scope of time and space to state Islamic orthodoxy in Indonesia and Malaysia from the late 1970s to present. I then choose three common topics found in Islamic education curriculum for senior high schools in Indonesia and Malaysia - pluralism/freedom of religion, marriage, and civic responsibility/governance - as examples of JAKIM's ideological dominance in Malaysia and the multifaceted nature found in Indonesian state Islamic orthodoxy.
\end{abstract}

Keywords: JAKIM, MUI, Islamic education, orthodoxy

\section{INTRODUCTION}

Both the pen and the sword are the instruments of the ruler to use in his affairs.

(Ibn Khaldun, 1967. The Muqaddimah: Volume 2). 
The wave of Islamic resurgence that hit the Muslim world in the late 1970s had sparked many Islamic political movements that posed serious existential threat to the regimes in power, which "non-Islamic governance" was hitherto perceived as a failure. The states in Malaysia and Indonesia established institutions - Malaysian Department of Islamic Development (Jabatan Kemajuan Islam Malaysia, JAKIM) and the Indonesian Council of Ulama (Majelis Ulama Indonesia, MUI), respectively - that specifically deal with the social Islamisation trend as the official arbiters of Islamic affairs. This article argues that JAKIM has been more successful in exerting its orthodox values on the society at large, and in particular the Islamic education curriculum, than MUI due to three factors: clear institutional objective; ideological cohesion among state institutions overseeing Islamic education; and patterns of Islamisation in the society that provide a conducive milieu for such orthodox ideals to thrive.

The first two factors can be attributed to the degree of institutional complexity of the state institutions that administer Islamic affairs in Malaysia and Indonesia, namely JAKIM and MUI, respectively. In a nutshell, the more complex the inter- and intra-relations between and within state institutions the less ideologically cohesive the state is, which this article argues lead to the formation of a more moderate and multifaceted state Islamic orthodoxy, such as the one we see in Indonesia. By the same token, a low degree of institutional complexity can also explain the formation and strength of the state Islamic orthodoxy in Malaysia. For the third factor, the varying patterns of social Islamisation in Malaysia and Indonesia necessitate the states to adopt different approaches in their dialectical interactions with the heightened religiosity within the society, which ultimately leads to a conservative version of state Islamic orthodoxy found in Malaysia and the multifaceted character of Islam in Indonesia (Nagata, 1984; Zainah, 1987; Chandra, 1987; Liddle, 1996; Abdul Azis, 1996; Hefner, 2000; Bertrand, 2004; Bahtiar, 2004). All three factors will be discussed in depth later in this article.

This article is organised as follows. I start with a brief discussion on the role of ideological hegemony in the maintenance of state legitimacy and its relation to the establishment of state Islamic orthodoxy as a means to control religious discourse. I then proceed to define the term orthodoxy and how orthodox values can vary diachronically from one country to another, depending on the political exigencies of the regime at a particular time in history, which in this paper is limited to the state Islamic orthodoxies in Indonesia and Malaysia from the late 1970s to present. Next I will provide background information on two Islamic institutions that claim to be the arbiter of orthodox values in Indonesia and Malaysia: MUI and JAKIM, respectively. By using the three aforementioned factors, I will then discuss why JAKIM has been more successful in asserting its orthodox values on the Malaysian society than MUI in Indonesia. Finally, I choose three common 
topics found in Islamic education curriculum for senior high schools in Indonesia and Malaysia - pluralism/freedom of religion, marriage, and civic responsibility/ governance - as examples of JAKIM's ideological dominance in Malaysia and the pluralist nature found in Indonesian state Islamic orthodoxy, among which MUI is one of several co-existing Islamic authorities such as Nahdlatul Ulama and Muhammadiyah.

\section{State Ideological Hegemony and Islamic Orthodoxy}

In the modern context, the quote at the beginning of the article denotes the sheer importance of equally employing blunt physical force and ideological discourse in the maintenance of a state's legitimacy to rule. It is not enough for a state to simply "claim the monopoly of the legitimate use of physical force within a given territory," per the oft-cited definition proffered by Weber (1946: 78). By solely attempting to extract compliance and obedience from the population through coercive forces such as the police, the military and the legal system, the state risks being perceived as cruel, and thus hated by its subjects. To paraphrase the 15 th century political theorist Machiavelli (1999: 55) in his treatise on the art of ruling, "a state should inspire fear in such fashion that if it does not win love it may escape hate." It is then imperative for the state to try winning the hearts and minds of the population as a way to lower the transaction costs of governance; in other words, minimising conflicts between the state and the society and also between the various components that make up the state. As such, the state needs to manufacture and instill a belief within the society and itself that its authority to rule is legitimate, indisputable and an organic part of the socio-political-economic order of the day; hence, the integral role of controlling ideological discourse in the maintenance of state legitimacy.

According to Michel Foucault, the productive aspect of state power cannot be expressed solely in the context of repression, or what he calls the "juridical conception" of state power. The power of the state traverses through the society, in which it "induces pleasure, forms knowledge, and produces discourse" (Gordon, 1980: 119). In other words, a state can only maintain its legitimacy and impose its ideological hegemony through a dialectical relationship with the society. Therefore, it is imperative for the state to establish "non-repressive" components that are able to socialise the population in its values, generate support through indoctrination and serve as a complement to the blunt repressive arms of the state such as the army, police, judiciary and so on. Louis Althusser terms the non-repressive components of the state as the "ideological state apparatuses," of which the schools, media, civil society, to name but a few, are part. The main function of the ideological state apparatus is to reproduce the dominant values in 
the society, which Althusser (1971: 145-149) argues are those which legitimate capitalist relations of exploitation. Antonio Gramsci calls this hegemonic set of values "historically organic ideology" (Forgacs, 2000: 199).

In response to the wave of Islamisation in the late 1970s, the state's imperative to exert its ideological dominance forms the raison d'être for the formulation and propagation of a state Islamic orthodoxy, as we shall see in the case of Malaysia. The conventional notion of Islamic orthodoxy proposes the state to develop its own interpretation of Islam, socialise that interpretation widely among the public, in the context of this paper, through mass education, and mete out proscriptions and punishments against alternative interpretations. The idea that a state Islamic orthodoxy is essentially a form of power dynamic is described by Talal Asad (1986: 15):

Orthodoxy is not a mere body of opinion but a distinctive relationship a relationship of power. Wherever Muslims have the power to regulate, uphold, require, or adjust correct practices, and to condemn, exclude, undermine, or replace incorrect ones, there is the domain of orthodoxy.

To merely explain orthodoxy in terms of a linear power relationship where the state unilaterally imposes its ideological will on the society at large is to overlook the complex process that gives shape and substance to the orthodox values and norms. Foucault describes this power dynamic in the form of a weblike structure of relations between the state and the society and the production of "truth" forms the basis on which the idea of orthodoxy is developed (Gordon, 1980: 98). One very detailed definition of orthodoxy describes it as:

[a] superordinate compulsory organization composed of a leading class in cahoots with other classes and social groups that 1) controls the means of material, intellectual, and symbolic production; 2) articulates "correct" forms of belief and praxis through the work of rationalizing and consentgenerating intellectuals (and/or priests); 3) identifies "incorrect" forms of belief and praxis through these same intellectuals; 4) institutionally manages deviant individuals and groups through coercive mechanisms (e.g., physical and symbolic violence, excessive taxation, ostracism, etc.) or through "re-education, " compromise, accommodation, and so on (Berlinerblau, 2001: 340).

Nonetheless, this definition of orthodoxy is only partially complete when applied to the context of this article as religious orthodoxy is not necessarily related to dominating and controlling other religious points of view, as we shall see in the Indonesian case. The state's utilisation of Islamic discourse for legitimacy assumes different shapes and meanings depending on the political exigencies of 
the particular time and place in history. It is therefore instructive to analyse Islamic orthodoxy in a similar light, namely in construing orthodoxy and its contents "[a]s fluid, as developing in a dialectic with heterodoxy" (Berlinerblau, 2001:332). Orthodox values and norms change over time in direct relation with the prevailing heterodox ideas and practices, and this article focuses on the period of Islamic resurgence in Malaysia since the late 1970s and in Indonesia since the late 1980s.

A state Islamic orthodoxy by definition must be promoted by state institutions as a means of controlling religious discourse. In order to explore the nature of the Islamic orthodoxy propagated by a state at any particular moment in time - in this article we are concerned with the Islamisation period in Indonesia and Malaysia - we need to consider the political utility for the state in formulating and institutionalising certain values that make up the state Islamic orthodoxy. One important aspect of orthodoxy is its characteristic as an "institutionalised ideology," meaning attempts at monopolising religious discourse through formal coercive powers of the state apparatus (Zito, 1983: 124). In other words, orthodoxy can only function within the framework of state institutions, which renders it official. While Islamic orthodoxies have existed since the beginning of Islam, the use of orthodoxy to prop up regime legitimacy in the Muslim world was irregular and capricious since the orthodoxy itself was highly dependent on the influence of the individual ruler and the feudal kingdom of the day. It was the rise of modern states in the Muslim world in the late 1800s with their attendant bureaucracies that gave orthodoxy a stable institutional home and provided its enforcers with more intrusive and coherent coercive powers. In short, an interpretation of Islam only becomes an orthodoxy if a state adopts it. In the words of Hamid Dabashi (1989: 71), "it is the political success of a given interpretive reading that renders a religious position 'orthodox."' In Malaysia, the institutional manifestation of a particular interpretation of Islam comes in the form of JAKIM, while in Indonesia it is the MUI.

\section{BACKGROUND INFORMATION ON JAKIM AND MUI}

\section{Malaysian Department of Islamic Development (JAKIM)}

The indisputable arbiter of Islamic orthodoxy in Malaysia is the Department of Islamic Development (Jabatan Kemajuan Islam Malaysia, JAKIM). JAKIM started as the National Council for Islamic Affairs in Malaysia (Majlis Kebangsaan Bagi Hal-Ehwal Agama Islam Malaysia, MKI) in 1968. In 1974, MKI's status was upgraded to a division under the Prime Minister's Office called Islamic Affairs Division (Bahagian Hal-Ehwal Islam, BAHEIS). BAHEIS's status was elevated to a department (Jabatan) in January 1997, in line with its increasing bureaucratic 
importance, which subsequently changed its name to what we now know as JAKIM. Currently JAKIM comprises 22 divisions and Islamic educational affairs (called Lembaga Penasihat Penyelarasan Pelajaran dan Pendidikan Agama Islam, LEPAI) which fall under the Islamic Development Division (Bahagian Kemajuan Islam). JAKIM's overall budget for 2015 is RM783,256,900 (USD188.8 million), a big part of which is used to fund an elementary Islamic education program called Kelas Al-Quran dan Fardhu Ain (KAFA) (Kementerian Kewangan Malaysia, 2015: 118). Three main functions of JAKIM are legislation and standardisation of Islamic laws, Islamic administration coordination, and adjustment and development of Islamic education.

JAKIM's views on various socio-political-economic issues can be found at e-fatwa website (http://www.e-fatwa.gov.my/admin/), an official online clearinghouse for all fatwas ever issued by the Meeting of Fatwa Committee of National Council on Islamic Affairs in Malaysia (Muzakarah Jawatankuasa Fatwa Majlis Kebangsaan Bagi Hal Ehwal Ugama Islam Malaysia) and the state religious authorities, and peruse its official publications such as Buletin JAKIM, Suara Masjid, and Buletin Hadhari (no longer in circulation). These publications are distributed among all government offices throughout the country and public institutions such as mosques and schools. They are also freely available for private organisations and individuals. In these publications, JAKIM prints fatwas on burning issues of the day, taushiyah (advices and recommendations), opinion essays, reports on policy meetings, seminars and workshops, announcement of staff promotions and transfers, among others. ${ }^{1}$ In short, JAKIM's publications can be accepted as the official vessel in which its views are carried and disseminated far and wide throughout the government and the society. It then follows that we are able to distill the orthodoxy's stance on various issues based on JAKIM's own published views, which are not only internally restricted within its own department.

\section{Indonesian Council of Ulama (MUI)}

The Indonesian Council of Ulama (Majelis Ulama Indonesia, MUI) is the closest one can find to being a national body that claims to speak on behalf of all Muslims in the country. President Sukarno first founded the Central Council of Ulama (Majelis Ulama Pusat) in 1962 that subsequently issued a fatwa claiming it was fardhu ain (an individual obligation) for every Indonesian Muslim to struggle against Malaysia during the Konfrontasi period (Mudzhar, 1993: 47). This nascent effort was abandoned a few years later when the Suharto's New Order regime took over in 1966 and was not revived until 1975. The present-day MUI was established on 26 July 1975 to provide "an alternative channel of state-Islamic interest intermediation and communication to that of the political parties" (Porter, 2004: 77). It was essentially a state-led creation that sought to co-opt main Islamic organisations from across the country. 
Currently MUI comprises of 73 member organisations chosen by the Central MUI (MUI Pusat) in Jakarta. Nationally, MUI has its branches in all 34 provinces and more than 400 districts (kabupaten), typically referred to as MUI Daerah (region). Technically, MUI Daerah has to refer to the fatwas of MUI Pusat on national issues and only allowed to issue their own fatwa on specific local issues that do not happen elsewhere in the country (only after consultation with MUI Pusat). ${ }^{2}$ In terms of organisational structure, MUI has 11 commissions that grapple with various policy issues and make recommendations to the MUI leadership board (Dewan Pimpinan) for further advocacy. MUI also consists of bodies that specialise in areas such issuance of fatwas (National Syariah Board, Dewan Syariah Nasional) and certification of halal products (Assurance Institute of Food, Drugs and Cosmetics, Lembaga Pengkajian Pangan, Obat-obatan dan Kosmetika). At the present, MUI receives around Rp 3 milyar (USD 231,033) from the national budget (Anggaran Pendapatan dan Belanja Negara, APBN), which barely covers its estimated annual expenses of Rp 25 milyar (USD 1,925,279). The rest of its income comes from halal certification fees (about 20\%), donations from the community and private enterprises, funding from local governments, and various fund raising efforts (Syafiq, 2013: 70). In short, as we can see later on, MUI's status as both insider and outsider of the government proves to complicate its efforts in becoming the sole authoritative voice of Islam in Indonesia.

MUI's stances on wide array of issues can be gleaned from namely three sources: fatwas, taushiyah, and articles in its official publication, Mimbar Ulama. MUI's fatwas and taushiyah are also published in Mimbar Ulama magazines, which are then distributed to various mosques, government offices and nongovernmental Islamic organisations across the country. Many past and present MUI leaders are well-known religious scholars and they regularly contribute their thoughts through articles in Mimbar Ulama. MUI is also not shy in publicly voicing out its opinions and therefore its views on important national issues can easily be found in all mainstream media in the country. In short, MUI's views on most major aspects of Indonesian life are well known publicly especially after the commercial publication of the massive compilation of its fatwas from 1975 to 2010 (Majelis Ulama Indonesia, 2011).

\section{WHY STATE ISLAMIC ORTHODOXY IN MALAYSIA IS STRONG AND COHESIVE?}

Since we have already established that Islamic values have to be ensconced within the state institutional structure to render them an orthodoxy, now we want to look at how and why the states in Indonesia and Malaysia adopt different types of Islamic orthodoxy at this particular period of time. As briefly mentioned before, 
this article contends that institutional objectives and ideological cohesion of state institutions that administer Islamic affairs and the patterns of social Islamisation play a crucial role when it comes to determining the nature and strength of state Islamic orthodoxy. The Malaysian and Indonesia cases clearly illustrate the ways these three factors shape the nature of Islamic orthodoxy and its influence in the society at large.

Firstly, JAKIM represents the face of Islamic orthodoxy in Malaysia and enjoys the status as an official component of the state with the clear objective of Islamising the state bureaucracy and the society, along with guarding the sanctity of Islam in the country (Malay Mail Online, 2015; The Malaysian Insider, 2015b). JAKIM has at its disposal the state's means of coercion, which then allows it a monopoly on religious ideas and practices; in other words, it enjoys hegemonic control over religious interpretive authority (The Malaysian Insider, 2015a). Therefore, Islamic values promoted by JAKIM are indistinguishable from the ones adopted by other state institutions. All the relevant state institutions share a clear institutional objective and cohesion (JAKIM, n.d. [b]). In 1985, the Malaysian government introduced Dasar Penerapan Nilai-Nilai Islam Dalam Pentadbiran (Inculcation of Islamic Values in Administration), an official policy that aimed to make Malay civil servants better Muslims with the belief that a devout Muslim is also a productive and honest worker (Jabatan Perdana Menteri, 2001). JAKIM also regularly coordinates with the state Islamic councils (Majlis Agama Islam Negeri) to ensure that all Islamic authorities are on the same ideological wavelength, namely because Islamic affairs fall under the purview of the sultan in each state. In regard to Islamic education, of which the states have traditionally held autonomy over Islamic schools and curriculum within their boundaries, JAKIM, through its division called Lembaga Penasihat Penyelarasan Pelajaran dan Pendidikan Agama Islam or LEPAI (Advisory Agency for the Streamlining Islamic Education and Islamic Studies), has managed to successfully bridge the differences and erode the states' rights over managing their own Islamic educational affairs, so much so a national curriculum for SAN, SAR and SABK will be implemented across Malaysia soon. ${ }^{3}$ The hegemonic influence of JAKIM's orthodox values is evident in the national curriculum content of the Islamic Studies subject (Pendidikan Islam) at the senior high school level, which will be discussed in detail later. In short, we can readily see the congruency of institutional objectives within both the vertical (federal-state) and horizontal (federal and state) axes of governance in Malaysia.

Secondly, when it comes to institutional ideological cohesion, there are barely any discernible differences between Islamic views propagated by JAKIM and the state Islamic councils. In addition to the previously mentioned Dasar Penerapan Nilai-Nilai Islam Dalam Pentadbiran, the Malay-dominated civil service and the ascendancy of pro-Malay policies, a result of the 1971 New Economic Policy (NEP), provided prime opportunities for newly empowered Malay-Muslim 
activists to Islamise the state institutions and to use the deep reach of the state to inculcate the Malay-Muslim society in the activists' own values. The percentage of Malays in managerial and professional positions within the civil service rose dramatically from $14.1 \%$ in 1957 to $67.8 \%$ by late 1999 (Khoo, 2005: 18-19). In 2008 the Malaysian government via the Prime Minister's Office, of which JAKIM is also part, established Islamic Consultative Council (Majlis Perundingan Islam, MPI), which currently consists of 87 members from various backgrounds such as civil servants, academics, ulama, CEOs, and heads of major Islamic NGOs. MPI's main function is to act as a "think tank" that helps the government to implement development policies based on Islamic principles (http://www.islam.gov.my/en/ mesyuarat-majlis-perundingan-islam). As a result, the ideological coherency of state institutions in Malaysia and their shared institutional goals of propagating a single unchallenged interpretation of Islam, run almost seamlessly from the center to the periphery of governance. The high degree of ideological congruency between various state institutions and the Malay-Muslim society allows the state in Malaysia to exert its ideological hegemony in the form of state Islamic orthodoxy more effectively with minimal interference from countervailing Islamic social groups.

Thirdly, the Islamisation wave in Malaysia since the late 1970s entailed abrupt institutional change, resulting in the reconfiguration of orthodox values and the rise of conservative brand of state Islamic orthodoxy. The Islamised society since the late 1970s presented a potent challenge to the state's legitimacy by framing the public discourse in an Islamic context, and thus prompting the state institutions to change and adapt. The values and norms of the state Islamic orthodoxy were developed in the 1980s by the policymakers within the government, spearheaded by the chief architect of the Islamisation process, Anwar Ibrahim, whom the former Prime Minister, Mahathir Mohamad, recruited away from the opposition-friendly Malaysian Islamic Youth Movement (Angkatan Belia Islam Malaysia, ABIM). This process occurred in a constant discursive engagement with the Islamic ideas and principles of Parti Islam Se-Malaysia (PAS), the opposition Islamic party that was challenging the regime on the grounds that it lacked religious legitimacy to govern. As the interplay of religious discourse between the state and its Islamic opposition produced more conservatism, so did the official orthodoxy which it engendered (Maznah, 2013: 106-109; Liow, 2009: 43-72; 2004: 184-205; Kamarulnizam, 2003: 180-211; Farish, 2003: 205). Presently, from the theological point of view, there are no major differences between the interpretations of Islam promoted by PAS and the United Malays National Organization (UMNO)-led government. Consequently, this ideological cohesion has allowed JAKIM to exert its values virtually unchallenged on the society at large, and in the context of this article, the Islamic education, even in the PAS-controlled state of Kelantan. 


\section{WHY THE STATE ISLAMIC ORTHODOXY IN INDONESIA IS FRAGMENTED AND PLURALIST?}

First, in contrast to JAKIM, MUI has never been a full-fledged government institution. As such, MUI lacks a core clarity of institutional purpose beyond certain policy areas such as halal certification and Islamic banking (Tempo, 2015; Lindsey, 2012: 262-272; Adams, 2012: 593-597). MUI has always occupied the awkward position of maintaining its independence as a non-governmental organisation while at the same time receiving financial, infrastructural and political support from the government. Throughout the New Order era (1966-1998) MUI was known to be the regime's rubberstamp (stempel pemerintah) due to its role in providing Islamic imprimatur for most of the regime's policies (Moch, 2010: 44; Syafiq, 2013: 55). It was not until 2000 when MUI made a clear attempt to break away from its long-held image of government apparatus. MUI at this time openly opposed the effort of the then President, Abdurrahman Wahid, to revoke the decision made by the Parliament in 1966 to ban the Indonesian Communist Party (Partai Komunis Indonesia, PKI) and any activities to propagate the ideas of Communism/MarxistLeninism (TAP MPRS Nomor XXV/MPRS/1966). It was a watershed point that marked MUI's transition from a supporter of the government to being its opposition, essentially an effort to rewrite its history of close association with the regime in power (Moch, 2010: 45; Mimbar Ulama, 2003a: 36-37; 2003b: 36-38).

The antagonistic relationship with the government continued into the then President Megawati's tenure (2001-2004) when her administration eliminated MUI's annual funding of Rp 5 milyar (USD 385,055 in present-day exchange rate) (Moch, 2010: 45). In short, the period between 2000 and 2004 saw MUI trying to rebrand itself from the government's Islamic rubber stamp to an independent social force that represents the Islamic aspirations of the Indonesian Muslim community. MUI leaders regularly refer to this transformation in the Arabic phrase: min khadim al-hukuma ila khadim al-umma (from the servant of the government to the servant

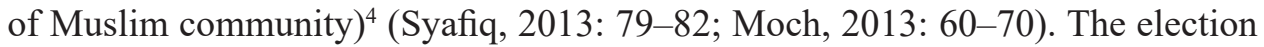
of Susilo Bambang Yudhoyono in 2004 brought a thaw in a relationship between MUI and the government (Lindsey and Pausacker, 2016; Mimbar Ulama, 2004c: 29-30). MUI started to play a closer role in advising the government on issues ranging from syariah banking and finance to halal products to morality-related policies such as the 2008 Pornography Law (Undang-Undang Nomor 44/2008 tentang Pornografi). At the same time MUI was also asserting its autonomy and institutional strength by becoming more publicly visible, namely through mass media coverage and mobilisation of grassroots support to vocally advocate its positions on some of the hotly debated legislative proposals (Moch, 2010: 47; 2013: 75-78). 
Second, the unclear status and institutional objectives of MUI greatly contribute to the lack of ideological cohesion found in state institutions that administer Islamic affairs in Indonesia. MUI, as mentioned before, is a membershipbased organisation and only a semi-official part of the state in Indonesia, with the proverbial other foot planted in the society. When it comes to instilling the state with its religious values, MUI often finds itself at odds with other institutions within the state due to its deeply conservative views but this relationship has become more cooperative since the election of former President Susilo Bambang Yudhoyono in 2004, arguably due to the President's perceived lack of religious credentials and Islamic grassroots support (Lindsey and Pausacker, 2016). MUI is not empowered with the state's means of coercion to implement and enforce its orthodox values, unlike its counterpart JAKIM in Malaysia. Therefore MUI typically has to resort to mobilising the Muslim masses when advocating its views on various legislations such as the aforementioned 2008 Pornography Law. MUI also faces challenges to its claim for interpretive authority from major Muslim organisations such Nahdlatul Ulama and Muhammadiyah, which are far more moderate and arguably more influential than MUI. In regards to Islamic education, MUI has long had deep ideological disagreement with the Ministry of Education and Culture (MOEC), particularly on the issue of single-roof education (pendidikan satu atap), in which the MOEC attempts (and fails) to absorb the management of Islamic schools and education into its ambit. Hence, despite MUI's claim to be the voice of orthodoxy in Indonesia, the reality reveals a more contested arena where heterodoxy retains major influence.

Third, the Islamisation of the Indonesian society that occurred in the 1980s did not pose a similar threat to the legitimacy of the New Order regime, like it did in the case of Malaysia. The Islamic resurgence mostly made its presence felt in the socio-cultural sphere, which, in turn, strengthened the preexisting ideological diversity within the Indonesian Muslim society (Aswab, 1990; Hefner, 1993: 8-12; Hefner, 2000; Bahtiar, 2004). Even then, the identity and ideology of the institution overseeing Islamic education (Ministry of Religious Affairs, MORA) remained unaffected and the influence of the arbiter of Islamic orthodoxy in Indonesia, MUI, also did not increase despite the apparent rise in pietism among the Indonesian Muslim population from about the mid-1980s (Hefner, 2000). The multifaceted nature of state Islamic orthodoxy in Indonesia is an indication of a state that is more divided and penetrable by various Islamic groups with ideologies that run the gamut from the progressive Jaringan Islam Liberal to the mainstream Nahdlatul Ulama and Muhammadiyah to the deeply conservative Hizbut Tahrir Indonesia and Front Pembela Islam. The lack of a clearly defined institutional objective, the ideological fragmentation between various state institutions (high degree of institutional complexity) and the patterns of social Islamisation that do 
not require the state to instrumentalise Islamic discourse for its political ends result in the dominance of diverse practices and define the values of Islamic orthodoxy in Indonesia and its pluralist ideals.

\section{EXAMPLES OF ISLAMIC VALUES FOUND IN THE NATIONAL CURRICULUM FOR ISLAMIC STUDIES}

There is plenty of topical overlap between the Pengetahuan Agama Islam curriculum in Indonesia and the Pendidikan Islam curriculum in Malaysia, both of which are taught at the senior high school level. The topics mainly revolve around matters of faith (aqidah), marriage and family, personal conduct, history of Islamic civilisation, history of Islam in Indonesia and Malaysia, and Muslim communal life, which includes governance and citizenship. These common topics, however, are where the similarity ends since the values that inform the content of the common topics are very different. The need of the state in Malaysia to legitimise itself from the Islamic perspective and the state's response to the growing religious conservatism in the society are manifested in the religious values incorporated in the Pendidikan Islam curriculum. Likewise, the lack of political utility of Islam as a regime legitimising force and the prevalent multifaceted Islamic practices in the Indonesian society allow the Pengetahuan Agama Islam curriculum to adopt a more moderate and inclusive interpretation when it comes to defining the religious values embedded within the curriculum, as opposed to adopting MUI's more hardline views.

We will look at three common topics to illustrate the differences in Islamic values and interpretations in the two countries' curricula: faith (aqidah), marriage, and governance/civic responsibilities. Examples are drawn from the study guidebooks for Pengetahuan Agama Islam and Pendidikan Islam at the senior high school level, which are widely available in major bookstores in both countries. When it comes to aqidah, it is clear that pluralist values are dominant in the Indonesian curriculum. For instance, the curriculum sees freedom of religion and religious pluralism as a human right and an essential component of the Indonesia's state motto Bhineka Tunggal Eka (Unity in Diversity). One textbook for senior high schools, by using Quranic interpretations from Surah Al-Kahf Verse 29 and Surah Al-Baqarah verse 256, states that:

In dealing with the differences in faith and religious practices, Muslims and non-Muslims must have the freedom of religion and to conduct the teachings of their religions, and cannot interfere in each other's affairs. Islam forbids compulsion in religion. ${ }^{5}$ 
In regard to religious pluralism and the need for multifaceted practices in fostering a tolerant society, the textbook states:

We have to realize that the words of God are very broad and multiinterpretative, so much so that we have to be aware of and respect the existence of many streams within a religion. ${ }^{6}$

In contrast, the curriculum for Pendidikan Islam in Malaysia contains no such endorsements of pluralism. It is very specific when it comes to defining what constitutes as the real teaching of Islam and what groups are considered deviants. The only acceptable version of Islam is the Ahli Sunnah Wal Jamaah (followers of Quran and the reported practices of the prophet Muhammad) version and Islamic sects such as the Shia, Khawarij, Qadiyani (Ahmadiyah), Bahai and Taslim are categorised as deviant teachings (ajaran sesat) (Johari, Abd Rahim and Sabri, 2012: 201-208). Furthermore, according to the curriculum there is no freedom of religion for Muslims and conversion out of Islam is punishable by death (Maimon et al., 2014: 47). This stands in sharp contrast to the previously mentioned example in the Indonesian textbook that does not list any deviant Islamic groups and places a strong emphasis on the non-compulsion aspect of Islam.

The topic of marriage is another example where we can tease out the differences in interpretation and ideological orientation between the curricula for Islamic education in Indonesia and Malaysia. Two glaring omissions, among others, in the Indonesian textbook can be found in its Malaysian counterpart: the right of a husband to hit his wife and polygamy. The Malaysian version explicitly permits the husband to hit his wife due to nusyuz (disobedience), which includes the wife's refusal to have sex with the husband, leaving the house without the husband's permission, behaving badly against the husband, disobeying the orders of her husband, and allowing an unrelated man into the house without the husband's knowledge (Johari, Abd Rahim and Sabri, 2012: 229). Instead of nusyuz, the Indonesian textbook places emphasis on the equality in marriage by stating that both husband and wife have equal rights and status in a marriage and should be treated equally in the eyes of law (Muchtar and Nashikun, 2011: 67). While the practice of polygamy is legal for Muslim men in Indonesia, the textbook simply does not discuss the issue under the broad topic of marriage. In contrast, the Pendidikan Islam subject in Malaysia devotes one lesson plan to the matter of polygamy, essentially sanctioning the practice as long as the man fulfills all the requirements, which are: not having more than four wives, acting justly with all the wives, and being physically and financially capable (Johari, Abd Rahim and Sabri, 2012: 235-237). These two issues - the right of a husband to hit his wife and polygamy - represent a conservative interpretation of Islam, which is clearly the ideals espoused by the curriculum in Malaysia; their omissions in the Indonesia curriculum, conversely, are an indicator of a more moderate Islamic interpretation. 
The topic of governance/civic responsibilities is another telling illustration of whether Islam serves a political utility to the state's sense of legitimacy. Treatment of the topic can indicate whether the state is using an Islamic interpretation to justify the political status quo. In the Indonesian curriculum, there is no evident attempt by the state to use Islamic values to prop up its legitimacy and extract compliance from the Muslim populace. The only lesson plan concerning citizenship and governance mainly touches on how the plural Indonesian society can remain united and harmonious while people respect each other's differences. There is no mention of the relationship between the citizenry and the political leadership (Muchtar and Nashikun, 2011: 119-124). Meanwhile, the Malaysian curriculum lists a host of citizens' responsibilities toward their political leaders, namely: obedience (which must be provided as long as one is not forced by the leaders to commit sins); unconditional support even if one does not like the leaders; and advising the leaders through proper and closed channels so as not to publicly shame them and the country in the eyes of the world (Johari, Abd Rahim and Sabri, 2012: 311-312; Malay Mail Online, 2016a; Malaysiakini, 2016). Under the topic of citizenship the Malaysian curriculum also justifies the use of repressive laws to save the country from its enemies and maintain stability (Johari, Abd Rahim and Sabri, 2012: 308). In short, it is clear that the state in Malaysia is actively trying to inculcate values in the Islamic education curriculum that it believes can legitimise its rule and preserve the status quo, as opposed to Indonesia, where no such attempt can be found.

The religious values one finds in Islamic education curricula in Indonesia and Malaysia are reflections of the states' dialectic relationships with Muslim society at large. The values found in the Indonesian curriculum reflect the multifaceted nature of Islamic practices in the society and the weak saliency of Islam as a rule-legitimizing force. The state in Indonesia does not have to compete with other socio-political Islamic forces for religious credibility, which typically results in a very conservative interpretation of Islam, as we can see in the Malaysian case. The fractured nature of the state institutions also explains why MUI, as the self-proclaimed arbiter of Islamic orthodoxy in Indonesia, has not been able to exert a more muscular and deep-reaching role in imbuing the state - including the education system - with its conservative values. In essence, there is a low degree of congruency between the values advocated by MUI and the values contained in the curriculum for Pengetahuan Agama Islam. ${ }^{7}$ Nevertheless, this is also not to say that values found in MORA's Pengetahuan Agama Islam curriculum is representative of Indonesian Muslim society as a whole. Definition of allowable Islamic practices within Indonesian Muslim society and inter-faith relations are still highly contested as evidenced by the discrimination and violence against the 
followers of Ahmadiyah and Shia and church closure controversies in some parts of the country (Lindsey and Pausacker, 2016). The fact that these multifaceted values are in constant state of flux across the society indicates that no one Islamic interpretation holds sway over others. In essence, the pluralist approach of the state Islamic orthodoxy in Indonesia allows for Islamic interpretations of all ideological stripes to co-exist and compete with each other.

In contrast, in Malaysia there is a high degree of congruency between the values espoused by JAKIM and the values found in the Pendidikan Islam curriculum. JAKIM regularly revises and streamlines the curriculum and textbooks for Islamic education and expects total compliance from teachers and students (Jabatan Kemajuan Islam Malaysia, 2009: 61). JAKIM acts as, borrowing the words of Althusser, the "state ideological apparatus," which tries to reproduce its own Islamic values in the society as a means to legitimise the state's hold on power (Malay Mail Online, 2016c). A highly religious and deeply conservative Malay-Muslim society partly informs the values held by JAKIM and other state institutions, which the state, in turn, reproduces in the society albeit in a form that is amenable to its political goal, which is to sustain its legitimacy. ${ }^{8}$ In other words, a monolithic interpretation of Islamic values shared by both the state and the MalayMuslim society in Malaysia allows the state to minimise disruptive influence from the Islamic social forces that can challenge its legitimacy, especially the opposition political party PAS.

\section{CONCLUSION}

Despite going through similar social Islamisation experience, the states in Malaysia and Indonesia have taken on different trajectories in dealing with this powerful stimulus. Their courses of actions are exemplified by the success (or lack thereof) of relevant state institutions in exploiting the wave of Islamic resurgence for their own political ends. In this article, I argue that the state in Malaysia has been more successful in advancing and enforcing its particular Islamic values on the society at large compare to its counterpart in Indonesia. The article uses the examples of JAKIM in Malaysia and MUI in Indonesia to illustrate the differences in institutional strength and reach of the state Islamic orthodoxy. The evidences found in the national curriculum for Islamic Studies further shed light on these differences. In sum, the success or failure of politically exploiting Islamic discourse through the promotion of state Islamic orthodoxy rests on its importance to the maintenance of state legitimacy, which is the case in Malaysia but not in Indonesia. 


\section{NOTES}

1. Theologically-speaking, fatwas are non-binding but in Malaysia fatwas assume the force of law once they are gazetted into the state's syariah law system, which are then enforceable on all Muslims residing in that particular state. In some states the failure to obey gazetted fatwas can result in a fine of no more than RM3,000 or maximum of two years in prison or both (Norliah, 2012: 95-102).

2. This is the reasoning used by MUI Pusat to justify the local fatwa issued by MUI Daerah in East Java that declared followers of Shia branch of Islam as infidels, which then led to the destruction of a Shiite settlement in Sampang on the island of Madura and the deaths of two villagers. MUI's stance was that the fatwa issued by MUI branch in East Java was locally unique to its social conditions and as such, was not applicable nationally. In addition, according to the MUI Pusat, the Shiite community in Sampang is different from Shiite communities in other parts of the country because other followers of Shia are less visible and non-confrontational, unlike the ones in Sampang. Interview with Amany Lubis, Deputy Secretary General of MUI Pusat, Jakarta, 3 January 2014. See also Mimbar Ulama, January 2013.

3. Interview with Azizan Muhammad, Ketua Penolong Pengarah Kanan Bahagian Kemajuan Islam (LEPAI), JAKIM, 21 March 2014. State Islamic Schools (Sekolah Agama Negeri, SAN), People's Islamic Schools (Sekolah Agama Rakyat, SAR), Government Assisted Islamic Schools (Sekolah Agama Bantuan Kerajaan, SABK).

4. Interview with Amany Lubis, Deputy Secretary General of MUI Pusat, Jakarta. 3 January 2014.

5. The original excerpt: "Dalam menyikapi perbedaan keimanan dan peribadahan itu, umat Islam dan kaum kafir hendaknya bebas beragama dan menjalankan ajaran agama yang dianutnya, dan tidak boleh saling mengganggu. Islam melarang memaksa orang lain untuk menganut sesuatu agama" (Pendidikan Agama Islam untuk SMA Kelas XII, 2007: 4).

6. The original excerpt: "Kita harus sadar bahwa firman Allah S.W.T., sangat luas dan multitafsir sehingga perlu sama-sama menyadari dan menghormati lahirnya berbagai aliran dalam satu agama" (Muchtar and Nashikun, 2011: 11).

7. The hardline values propagated by MUI stand in stark contrast to the more moderate ones found in the Pengetahuan Agama Islam curriculum. For example, MUI issued a fatwa in 2005 that declared pluralism, liberalism and secularism to be against the tenets of Islam. MUI had also issued fatwas against Shia and Ahmadiyah groups (Majelis Ulama Indonesia, 2011: 40-41, 46-47, 87-95, 96-99; Syafiq, 2016: 211233). When it comes to marriage, MUI adopts a patriarchal view that a wife must choose family over career (Mimbar Ulama, 2004a: 45; 2004b: 42-44). In regard to politics and governance, MUI is highly nationalistic and supports a more centralised Indonesia as it sees decentralisation as a precursor to widespread multifaceted Islamic practices (and a weakening of its role as the country's arbiter of Islamic values). (Mimbar Ulama, 1999a: 28-29; 1999b: 33-34). See also Syafiq (2015: $1-9)$. 
8. A Spring 2015 Global Attitudes survey by the Pew Research Center of eleven countries with significant Muslim population that gauges the population's views on Islamic State of Iraq and the Levant (ISIS), an international Islamic terror group, shows that higher number of Indonesians (79\%) are not in favour of ISIS compared to $64 \%$ in Malaysia. More tellingly, $11 \%$ of Malaysians have a favourable view of ISIS compared to only $4 \%$ in Indonesia. http://www.pewresearch.org/facttank/2015/11/17/in-nations-with-significant-muslim-populations-much-disdainfor-isis/ (accessed on 19 November 2015). A 2011 survey by Goethe Institute and Friedrich Naumann Foundation for Freedom in collaboration with the Merdeka Centre for Opinion Research in Malaysia showed that almost $81 \%$ of Muslim youth (15 to 25 years old) in Malaysia defined themselves as Muslim first, not Malaysian or Malay while more than $70 \%$ wanted the Quran to replace the Constitution. http://www.goethe.de/ins/id/pro/jugendstudie/jugendstudie_en.pdf (accessed on 1 February 2016). These two surveys serve as an indicator of the deep religious conservatism that is prevalent within the Malay-Muslim population in Malaysia.

\section{REFERENCES}

Abdul Azis Thaba. 1996. Islam dan negara dalam politik orde baru. Jakarta: Gema Insani Press.

Adams, H. Wahiduddin. 2012. Fatwa MUI dalam perspektif hukum dan perundangundangan. In Fatwa MUI dalam perspektif hukum dan perundang-undangan. Jakarta: Puslitbang Lektur dan Khazanah Keagamaan, Kementerian Agama Republik Indonesia.

Aswab Mahasin. 1990. The Santri middle class: An insider view. In The politics of middle class Indonesia, eds. R. Tanter and K. Young. Clayton: Monash University Centre of Southeast Asian Studies.

Althusser, L. 1971. Lenin and philosophy and other essays. London: NLB.

Bahtiar Effendy. 2004. Islam and the state in Indonesia. Athens: Ohio University Press.

Berlinerblau, J. 2001. Toward a sociology of heresy. History of Religions 40(4): 327-351. https://doi.org/10.1086/463647.

Bertrand, J. 2004. Nationalism and ethnic conflict in Indonesia. Cambridge and New York: Cambridge University Press.

Chandra Muzaffar. 1987. Islamic resurgence in Malaysia. Kuala Lumpur: Fajar Bakti.

Farish Noor. 2003. Blood, sweat and jihad: The radicalization of the political discourse of PAS from 1982 onwards. Contemporary Southeast Asia 25(2): 200-232. https:// doi.org/10.1355/CS25-2B.

Forgacs, D., ed. 2000. The Gramsci reader: Selected writings 1916-1935. New York: New York University Press.

Gordon, C., ed. 1980. Power/knowledge: Selected interviews and other writings, 19721977 by Michel Foucault. New York: Pantheon Books. 
Hamid Dabashi. 1989. Authority in Islam: From the rise of Muhammad to the establishment of the Umayyads. New Brunswick, N.J.: Transaction.

Hefner, R. 2000. Civil Islam: Muslims and democratization in Indonesia. Princeton and Oxford: Princeton University Press.

. 1993. Islam, state, and civil society: ICMI and the struggle for Indonesian middle class. Indonesia 56 (October): 1-36.

Ibn Khaldun. 1967. The Muqaddimah: Volume 2, translated by Franz Rosenthal. Princeton: Princeton University Press.

Jabatan Kemajuan Islam Malaysia. 2009. Pelan tindakan strategik JAKIM 2009-2014: Memacu transformasi pengurusan hal ehwal Islam. Putrajaya: Jabatan Kemajuan Islam Malaysia.

. n.d. [a]. Mesyuarat Majlis Perundingan Islam. http://www.islam.gov.my/en/ mesyuarat-majlis-perundingan-islam (accessed on 15 February 2016).

. n.d. [b]. Persidangan Ketua Jabatan/Majlis Agama Islam Negeri Seluruh Malaysia (PKJ) Kali Ke-97. http://www.islam.gov.my/node/51923 (accessed 19 February 2016).

Jabatan Perdana Menteri. 2011. Garis panduan bagi mengadakan ceramah penerapan nilai-nilai islam dalam perkhidmatan awam: Pekeliling Am Bil. 2 Tahun 2001. Putrajaya: Jabatan Perdana Menteri.

Johari Johar, Abd Rahim Ab Halim, and Sabri Ab Ghani. 2012. Success Pendidikan Islam $S P M$. Kuala Lumpur: Oxford Fajar.

Kamarulnizam Abdullah. 2003. The politics of Islam in contemporary Malaysia. Bangi: Universiti Kebangsaan Malaysia Press.

Kementerian Kewangan Malaysia. 2015. Anggaran perbelanjaan persekutuan 2015. http://www.treasury.gov.my/index.php?option=com_content\&view=article\&id= 4298:anggaran-perbelanjaan-persekutuan-2015\&catid=447\&Itemid=2473\&lang $=\mathrm{ms}($ accessed 12 October 2015).

Khoo Boo Teik. 2005. Ethnic structure, inequality and governance in the public sector: Malaysian experiences. United Nations Research Institute for Social Development, Democracy, Governance and Human Rights Programme, Paper Number 20.

Liddle, W. 1996. The Islamic turn in Indonesia: A political explanation. Journal of Asian Studies 55(3): 613-634. https://doi.org/10.2307/2646448.

Lindsey, T. and H. Pausacker, eds. 2016. Religion, law and intolerance in Indonesia. Oxon and New York: Routledge.

Lindsey, T. 2012. Monopolising Islam: The Indonesian Ulama council and state regulation of the "Islamic Economy." Bulletin of Indonesian Economic Studies 48(2): $253-$ 274. https://doi.org/10.1080/00074918.2012.694157.

Liow, J. 2009. Piety and politics: Islamism in contemporary Malaysia. New York: Oxford University Press. https://doi.org/10.1093/acprof:oso/9780195377088.001.0001. 2004. Political Islam in Malaysia: Problematising discourse and practice in the UMNO-PAS "Islamisation race." Commonwealth and Comparative Politics 42(2): 184-205. https://doi.org/10.1080/1466204042000299254.

Machiavelli, N. 1999. The Prince. New York: Barnes \& Noble Books.

Maimon Husin, Apendi Sahi, Zulhazmi Omar and Mohammad Zaini Yahya. 2014. Nexus Tuntas SPM 4-5: Pendidikan Islam. Petaling Jaya: Sasbadi Sdn. Bhd. 
Majelis Ulama Indonesia. 2011. Himpunan fatwa MUI sejak 1975. Jakarta: Sekretariat Majelis Ulama Indonesia.

Malaysiakini. 2016. Murid perlu ditanam rasa taat pada pemimpin, negara - Mahdzir. 30 April. http://www.malaysiakini.com/news/339825.

Malay Mail Online. 2016a. Disloyalty to leader is disloyalty to God, Muslims told in Friday sermon. 18 March. http://www.themalaymailonline.com/malaysia/article/ disloyal-to-leaders-is-disloyalty-to-god-muslims-told-in-friday-sermon.

. 2016b. Deputy Minister admits Putrajaya funds Islamic groups, including Isma. 13 February. http://www.themalaymailonline.com/malaysia/article/deputyminister-admits-putrajaya-funds-islamic-groups-including-isma.

2016c. Allah hina rakyat tidak hormat pemimpin, kata JAKIM. 11 March. http:/www.themalaymailonline.com/projekmmo/berita/article/allah-hina-rakyatyang-tidak-hormat-pemimpin-kata-jakim

. 2015. Putrajaya: Jakim benteng negara tangani Syiah, Islam liberal, IS.10 November. http://www.themalaymailonline.com/projekmmo/berita/article/ putrajaya-jakim-benteng-negara-tangani-syiah-islam-liberal-is.

Maznah Mohamad. 2013. Legal-bureaucratic Islam in Malaysia: Homogenizing and ringfencing the Muslim subject. In Encountering Islam: The politics of religious identities in Southeast Asia, ed. Hui Yew-Foong. Singapore: Institute of Southeast Asian Studies.

. 2010. The ascendance of bureaucratic Islam and the secularization of Sharia in Malaysia. Pacific Affairs 83(3): 505-524. https://doi.org/10.5509/2010833505.

Mimbar Ulama. 2013. Fatwa MUI Jawa Timur tentang Syiah: Sudah sesuai aturan. January. 2004a. Tidak mentaati orang lain selain suami. February.

2004b. Perkahwinan: Antara karir dan keluarga. May.

2004c. Susilo Bambang Yudhono [sic]: Dari pesantren hingga kedekatannya dengan ulama. October.

2003a. Mewaspadai bahaya Komunisme. September.

. 2003b. Mencabut tap MPRS XXV/1966 menghidupkan kekejaman PKI. October.

1999a. Usul Majelis Ulama terhadap RUU tentang pemerintahan daerah dan konsep satu atap Mahkamah Agung. April.

1999b. Menyoroti RUU pemerintahan daerah dan peradilan satu atap: MUI kembali datangi DPR. April.

Moch Nur Ichwan. 2013. Towards a puritanical moderate Islam: The Majelis Ulama Indonesia and the politics of religious orthodoxy. In Contemporary developments in Indonesian Islam: Explaining the conservative turn, ed. Martin van Bruinessen. Singapore: Institute of Southeast Asian Studies.

. 2010. Politik metamorfosis Majelis Ulama. Mimbar Ulama (June): 44-48.

Muchtar and Nashikun. 2011. Pendidikan Agama Islam untuk SMK dan MAK Kelas XII. Jakarta: Penerbit Erlangga.

Mudzhar, M. A. 1993. Fatwa-fatwa Majelis Ulama Indonesia: Sebuah studi tentang pemikiran hukum Islam di Indonesia, 1975-1988. INIS: Jakarta.

Nagata, J. 1984. Reflowering of Islam: Modern religious radicals and their roots. Vancouver: University of British Columbia Press. 
Norliah Sajuri. 2012. Institusi fatwa di Malaysia in Prosiding Seminar Kebangsaan Penyelarasan Penguatkuasaan Fatwa di Malaysia. Jabatan Kemajuan Islam Malaysia: Putrajaya.

Porter, D. 2004. Managing politics and Islam in Indonesia. Routledge Curzon: London and New York.

Syafiq Hasyim. 2016. The council of Indonesian Ulama (MUI) and Aqida-based intolerance: A critical analysis of its fatwa on Ahmadiyah and 'Sepilis'. In Religion, law and intolerance in Indonesia, eds. T. Lindsey and H. Pausacker. Oxon and New York: Routledge.

.2015. Majelis Ulama Indonesia and pluralism in Indonesia. Philosophy and Social Criticism 41(4-5): 1-9. https://doi.org/10.1177/0191453714566547.

. 2013. Council of Indonesian ulama and its role in the shariatisation of Indonesia. $\mathrm{PhD}$ diss., Free University Berlin.

Syamsuri. 2007. Pendidikan Agama Islam untuk SMA Kelas XII. Jakarta: Penerbit Erlangga.

Talal Asad. 1986. The idea of an anthropology of Islam. Washington, DC: Center for Contemporary Arab Studies, Georgetown University.

Tempo. 2015. Gus Mus: MUI itu sebenarnya makhluk apa? 1 April. https://nasional.tempo. co/read/news/2015/04/01/173654579/gus-mus-mui-itu-sebenarnya-makhluk-apa (accessed 15 June 2015).

The Malaysian Insider. 2015a. JAKIM critic Tawfik Ismail faces sedition probe. 24 November.

. 2015b. Who else can defend Islam if not JAKIM, says director-general. 18 November.

Weber, M. 1946. Politics as a vocation. In From Max Weber: Essays in sociology, eds. H. H. Gerth and C. Wright Mills. New York: Oxford University Press.

Zainah Anwar. 1987. Islamic revivalism in Malaysia: Dakwah among the students. Kuala Lumpur: Pelanduk Publications.

Zito, G. 1983. Toward a sociology of heresy. Sociological Analysis 44(2): 123-130. https://doi.org/10.2307/3711397. 